\title{
FABP6 wt Allele
}

National Cancer Institute

\section{Source}

National Cancer Institute. FABP6 wt Allele. NCI Thesaurus. Code C118967.

Human FABP6 wild-type allele is located within 5q33.3-q34 and is approximately $51 \mathrm{~kb}$ in length. This allele, which encodes gastrotropin protein, is involved in bile acid and bile salt transport. 